\title{
A Political Economy of Russian Nature Conservation Policy: Why Scientists have Taken a Back Seat
}

\author{
David Ostergren and Peter Jacques
}

The fall of the USSR revealed the depth of Russia's environmental crisis to both the world and the Russian people, despite early indications during President Gorbachev's policies of glasnost. ${ }^{1}$ As the public raised its voice over the crumbling regime, policy-makers changed the way that Russia approached the environment. ${ }^{2}$ At the same time, the country was adopting the foundations for a democratic, multiparty political system and the tenets of free market capitalism. If indeed there was an underlying change in political economy, the implication is that policy-makers would use environmental policy processes that were compatible with the emerging Russian liberal project.

In support of this hypothesis, the adoption of the expertiza (SER) and the post-Soviet addition of public participation (PER) indicate increased liberalism in environmental policy-making. Key authors reviewed the liberal environmental laws of Western European, United States' and Canadian environmental legislation who constructed the 1995 Law on Specially Protected Natural Areas. We contend that the threat of institutionalizing a liberal political economy in Russia provided specific requirements and boundaries for policy choices. As a result, natural resource policy had to be configured within these liberal constraints, such as requirements for public participation and state decentralization.

The effects of liberalism upon the post-Soviet social organization has not received adequate systematic investigation. ${ }^{3}$ We find that liberalism has had a direct effect on environmental policy as evidenced by a change in the institutional role of Russian scientists who have taken a back seat in the policy-making process. While Soviet environmental management left much to be desired, the change to a liberal environmental policy has further endangered natural resource protection, particularly of the Russian key preserves and national parks.

1. Feshbach and Friendly 1992; Peterson 1993; and Pryde 1995.

2. Cherp 2000; Cherp and Lee 1997; and Porfiriev 1997.

3. See Suda 2000 who notes more research in general is needed; and Cohen 2000 who notes what research has been done has been skewed by pressures from the US. 
In other words, Russian ecosystems have leapt from the communist frying pan, into the liberal fire.

Consistent with past research, ${ }^{4}$ we acknowledge the existence of Soviet era interest groups and that the expanding Russian variation of pluralism predates the 1991 revolution. ${ }^{5}$ We also recognize that the failing economy has limited the ability of the Russian government to support science. However, the nature of participation for conservation scientists has fundamentally changed. As economic, production and inner circle interests command more power in policymaking, the scientists have dropped from an elite group, to one of many interests in the lower tiers of power. While the survival of democracy in Russia is questioned by several authors, ${ }^{6}$ our analysis suggests that the very liberalism that is a hallmark of democracy may be a culprit in weakening scientists' ability to critique environmentally poor projects, create sound environmental policy and/or direct preservationist efforts because there are more actors and less direct access.

\section{Methodology}

We base our findings on data collected in 1994 and 1995, and again in 1999 and 2000 by David Ostergren. Structured, open ended interviews were conducted on nature preserves in Central Siberia and the Black-Earth region in an effort to understand the changing politics of nature conservation in post-Soviet Russia. Ostergren interviewed officials at the central administrative offices in the Moscow Department of Zapovednik Management and the Federal Forest Service, members of various nongovernmental organizations, a wide range of employees from protected areas and academic experts. Protected Areas included in these interviews were the Altaisky, Katunski, Tiamirski, Putoranski, Stolby, Sayan-Shushenski, Voronezh, Central Black Earth, and Galichya Zapovedniks as well as Pribailkalski National Park.

Ostergren conducted a series of structured, open ended interviews with nearly 100 individuals connected to protected areas and conservation. Interviewees included zapovednik and national park elites, policy analysts from Russian and international nongovernment organizations (NGOs), administrators in Moscow, as well as academics from Moscow State University and other regional State Universities. Data from the interviews were corroborated with round table discussions at conferences in Russia, research in archival sources and publications on specially protected area policy (publications were in Russian and English as well as internal and external to the agencies). We have also used continued correspondence with key Russian policy-makers who drafted environmental policy.

4. Skilling and Griffiths 1971.

5. See for example Goldman 1972; Lubrano and Gross-Solomon 1980; Saivetz and Jones 1994; and Jancar-Webster 1993.

6. Among others, see Eckstein et al. 1998, and Bonnell and Breslauer 2001. 
The scientific community is comprised of diverse interests which represent a full range of policy opinions. Some support utilization while others promote the preservation of natural resources. The bulk of this sample was drawn from scientists who may be characterized as generally "pro-conservation." This group is not necessarily anti-development, but only concerned that development includes providing a safe living environment and protecting the integrity of natural ecosystems. In Russia, as throughout the world, this position often puts conservationists at odds with official policy and projects.

\section{Liberal Political Theory}

The influence that liberalism has had on Russian policy-makers is unmistakable. Russian policy, indeed Russian ecosystems, must now survive sustained, plural demands in a way that it did not before. This attempt to decentralize and rhetorically empower individual competitiveness in politics and markets-to (at least rhetorically) segregate civil society from the state-is the Russian liberal project. Of note, within the Russian liberal project, liberalism was a broad ideological force that did not entertain a clear distinction between economic and political liberalism. ${ }^{7}$

This article will refer to liberalism in the same broad spirit where the rhetoric of individual rights, limited state intervention, market capitalism, and interest group competition are the prominent organizing principles for politicaleconomic governance. After the fall of the dominating Communist Party of the Soviet Union (CPSU) and the centralized Soviet state, liberal ideology appeared to be the only alternative.

Boris Yeltsin declared the official beginning of the Russian liberal project in October 1991 when he said, "We must . . . provide economic freedom, lift all barriers to the freedom of enterprises and of entrepreneurship and give people the opportunity to work and to receive as much as they can earn, casting off all bureaucratic constraints." ${ }^{8}$ Despite the negative effects of virtually unrestrained executive power, ${ }^{9}$ a stagnant, largely informal economy, ${ }^{10}$ and that the state has failed to provide many basic features of a fully operational government, ${ }^{11}$ by the late 1990s Russia was more democratic and seemed more decentralized than it did prior to $1991 .{ }^{12}$

The policy process for environmental policy (i.e. nature conservation policy) should reflect this shift. One key presumption is that environmental policy, in order to be operable, must not contradict the perceived larger political economy. While correspondence with Russian policy-makers demonstrates that Western environmental policies did not have a hegemonic influence (i.e. they

7. Weigle 2000; and White 2000.

8. Quoted in White 2000, 123.

9. Fish 2001.

10. Gaddy and Ickes 2001.

11. Bonnell and Breslauer 2001.

12. Sakwa 1996, 377; and Parrott 1997. 
were not externally forced upon Russia), the fall of the Soviet Union allowed forces of liberalism to come spilling over the fragmented dikes of post-Soviet Russia. Part of this flood of liberal influence was a legion of financiers, policy advisors, academics, and Western journalists, who, according to Stephen Cohen, took on an evangelical mission of helping Russia with its "shock therapy" of fast moving political-economic reforms. ${ }^{13}$ This is not to say that Russian officials were not making their own choices, but that there was a great deal of liberal pressures in Moscow that were not there before.

As policy-making decentralized (e.g. CPSU dissolved), Russia could no longer provide centrally planned protection to natural areas. Important legislators saw this new liberal political climate as a threat to Russian natural systems. As a result, policy-makers actively looked to the West for policy approaches compatible both with liberalism and environmental protection. It is at this point that Russian law changed many standards of citizen participation and institutionalized individual and group input.

Although Soviet era legislation often included "citizen input," these clauses were regularly ignored in the face of a centralized political system..${ }^{14} \mathrm{Not}$ until the policies of glasnost and perestroika did the people take to the streets and openly criticize government policy and practice. As one unforeseen result of this liberal project, Russian scientists have been marginalized from their former position as elite participants in the new liberal project by interest groups vying for policy space.

\section{Liberalism and US Environmental Policy}

Since liberal government can not blatantly act on a pre-determined notion of the good, it relies on interest groups to compete for policy space to determine multiple and competing policy goals. Thus, individuals participate in an Environmental Impact Statement (EIS) through comments, lobbying representatives, and even filing suits. The 1970 National Environmental Protection Act, the 1973 Endangered Species Act, the Clean Water Act, and the Clean Air Act (and amendments) are all examples of major US environmental laws that rely on interest groups to make substantive claims and changes.

As the above list implies, environmental policy in the United States bears little deviation from the modern liberal project of Western policy. Generally, Zachary A. Smith acknowledges that many of the liberal values within the Western dominant social paradigm such as rhetorical preference for free markets, individualism, and the appearance of objective science and technology, explain most environmental policy in the United States. ${ }^{15}$

13. Cohen 2000

14. Cherp 2000.

15. Smith 2000, 23. Smith has argued for many years now that "... the DSP in the United States has driven our history, our attitudes toward environmental regulation, and will continue to shape public policy responses to environmental problems in the future." 
Also, Sharon Ridgeway shows that US environmental policy, especially under cost-benefit analysis has impeded important ethical questions from being asked, e.g. those about wanton environmental destruction, because they hide under the (facade of) value-neutrality in the liberal state. ${ }^{16}$ She warns that cost benefit analysis is forced to view nature as a mechanism which obscures human-nature relationships and endangers the planet.

The implications that US environmental policy is a modern liberal project are important. Liberalism is a powerful and self-replicating force which can easily be counterproductive to conservation and preservation since the resultant policies exist comfortably in a individualist, mechanistic market atmosphere. Kirkpatrick Sale concludes that the United States Congress, in relation to environmental policy, took the stance, "we will tinker, ... we may even regulate, but we will not fundamentally alter the economic or political systems that produce the perils we are asked to confront." ${ }^{17}$ Thus, when Russian policy-makers borrow from US environmental policy, they are borrowing a liberal framework that fulfills liberal policy requirements. It is difficult to imagine that any significant deviation from these requirements could occur in the larger apparent liberal US political economy.

\section{Soviet Science, Environmental Protection, and the State}

\section{Soviet Environmental Policy}

The failure of legislation to adequately protect the environment in the Soviet Union is well documented. ${ }^{18}$ From 1917-1991 decisions from the Central Administration were characterized by a focus on material gain, an ignorance of ecological consequences, and a lack of democratic public commentary. Examples include: the failed White Sea-Baltic Sea Canal, the Great Stalin Plan for the Transformation [control] of Nature that sought to replace wild nature with managed nature, ${ }^{19}$ Khrushchev's Virgin Lands Project to bring vast areas of steppe under cultivation ${ }^{20}$ the use of nuclear power including detonations to move land, irrigation and the Aral Sea disaster, ${ }^{21}$ and the timber harvesting practices in European Russia. ${ }^{22}$ Soviet environmental policies left a legacy of depleted resources and a series of dangerous environmental health issues.

16. Ridgeway 1996, 4. She notes that humanity faces an existential crisis but under liberal values which "encourag[e] a human relationship of domination and control of nature," the ideological sources of our crisis remain largely unchallenged.

17. Sale 1993, 37.

18. See generally Feshbach and Friendly 1992; Komarov 1980; Pryde 1991; Pryde 1995; Peterson 1993; and Peterson 1995.

19. Weiner $1999,88$.

20. Komarov 1980.

21. Peterson 1993, 5-6, and 111-117.

22. Barr and Braden 1988. 
Environmental policy was often written with strict instructions to protect the environment but policy was in fact a goal to strive for rather than a standard to which to hold industry. Centralized edicts on nuclear power, dam building, manufacturing operations, and mining and timber enterprises dictated Soviet environmental practices while universally ignoring the strict "protection" policies. ${ }^{23}$ Some failures of environmental law in the Soviet Union may be attributed to the repression of citizen participation in the Soviet legislative process. Leaders often issued decrees and the Supreme Soviet rubber stamped associated legislation. ${ }^{24}$ The lack of public input meant that laws were constructed at the federal level without incorporating local idiosyncrasies for conservation or pollution prevention. ${ }^{25}$ State owned operations ignored environmental regulations knowing that close political ties were more influential than legal regulations and few judges would rule against them. A ruling in one court had no practical bearing on the outcome of a later case and judges called CPSU officials for guidance. $^{26}$

The scientific community has always been a respected and influential segment of Russian society. ${ }^{27}$ Although science is (in theory) objective, as in all nations, Soviet scientists were not monolithic in ideology. Since the concept of specially protected natural areas emerged late in the 1800s, scientists supported both pro-development policy and conservation/preservationist policy. ${ }^{28}$ As projects were undertaken by the government to create energy, extract raw material or utilize natural resources scientists were necessarily part of the process. $\mathrm{Al}$ though individual opinion was restrained under Soviet rule, individuals were able to influence policy as a part of the planning process and (naturally) according to their pro-development or pro-preservationist ideology.

The scientific community's influence may be described in two broad categories. One was where scientists approved government projects as proposed, or with slight, "Party acceptable" modifications. Scientists who agreed with the CPSU could maintain institutional influence beyond those who disagreed. Nonetheless, while being subject to indisputable Party power, individuals and interest groups were able to successfully oppose some state plans in order to establish some form of institutionalized environmental protection. ${ }^{29}$ For seventy years, scientists had access to information not available to the general public and many struggled to minimize damage by the state. Enormous pressure was brought to bear on scientists who were critical of projects including prison, banishment, a reduction of financial support, no approval for research, or the suppression (destruction) of an individual's career and sometimes death. ${ }^{30}$ In gen-

23. Ziegler 1987.

24. Zeigler 1987, 45.

25. Shaposhnikov and Borisov 1958; and Peterson 1993, 15-18, 175.

26. Komarov 1981; and Ziegler 1987, 78-101.

27. White 2000, 110 .

28. Weiner 1999; Weiner 1988; and Shtil'mark 1996.

29. Gustafson 1981; and Pryde 1972.

30. Weiner 1999; and Jancar-Webster 1987. 
eral, input on policy development was rarely sought nor casually offered. This point deserves highlighting: we do not argue that scientists controlled Soviet environmental policy-they clearly were subordinate to the Communist Party in this respect. The second category of policy influence occurred through criticism and information with which the scientific community contributed to public sentiment or, later in the 1980 s, public protest. Within the nature conservation community, preservationist ideals were passed from professor to student decade after decade. First privately, and then publicly, criticism was aired through the media, in addition to expert opinion registered in official policy-making. The turning point in public criticism of government environmental policy was the 1950s-1960s debate over constructing a pulp mill on Lake Baikal. ${ }^{31}$ The pulp mill threatened to pollute Lake Baikal, an icon of purity and beauty. The resistance was strong among scientists as well as writers and other artists. The debate demonstrated how Soviet era scientists (raised and trained under repressive regimes) understood how to work around the system. Scientists were responsible for getting the news out to the international community and, although the pulp mill was constructed and continues to spill effluent into Lake Baikal, the government acknowledged the need for some environmental regulations. The debate illustrates the role of the scientific community as part of the Soviet era policy-making process.

A further example of the scientific community's role was the Siberian river diversion project. In the 1970s, it was apparent even to Moscow administrators that irrigation projects in Central Asia had utterly ruined the Aral Sea. The Aral was drying up as in-flowing rivers were spread onto cotton crops. A plan emerged to replenish the Aral by diverting (essentially reversing the flow) of several Siberian rivers. The rivers diversion project was noteworthy because despite support in Hydrological Ministries, the CPSU and the Politburo, the project was effectively abandoned in part because scientists discredited the benefits and highlighted the costs. ${ }^{32}$

An important aspect of the public discourse and the role of scientists in the policy process was the very nature of how information was shared. ${ }^{33}$ Scientists understood the grim environmental conditions and passed this information on to their children. ${ }^{34}$ The children of the 1960 s and 1970s as scientists themselves, or through student protests, became the outspoken voices for environmental reform and were some of the most powerful guardians of nature through the 1980s. ${ }^{35}$ Some of the most effective NGOs in Russia are populated with these students-these children of the 1970s and 1980s. ${ }^{36}$

31. Gustafson 1981; Kelly 1976; and Josephson 1997.

32. Micklin 1986; and Darst 1988.

33. Yanitsky 1993.

34. Peterson 1993; Pryde 1995; and Yablokov and Ostroumov 1991.

35. Weiner 1999.

36. Yanitsky 1993. 


\section{Specific Russian Environmental Policy Provisions}

The public clamor for environmental protection surged in the 1980s. For example, in 1985 the first environmental impact analysis surfaced. ${ }^{37}$ By the late $1980 \mathrm{~s}$ general public protests against water and air pollution, hydro-electric dams and nuclear power continued to incorporate scientific evidence. Environmental issues undoubtedly contributed to the collapse of the U.S.S.R. ${ }^{38}$ This era of perestroika into the early 1990 s was a high point for citizen concern and scientific influence. After 1991 the Russian Federation began to reconsider and rewrite laws regulating the environment and has continued the process of rewriting the entire body of environmental laws from the Soviet era down to the present day. ${ }^{39}$ Granted, much of the terminology in these laws is inherited from Soviet era legislation. ${ }^{40}$ However, the legislation stands out from the Soviet era by its liberal measures for specifying public participation and codifying protective regulations which empower local authorities.

In natural resource policy, the 1995 Law on Specially Protected Natural Areas (SPNAs) requires public participation, similar to the requirement in the United States' NEPA. The legislation was drafted in the waning days of the Gorbachev regime and revived in 1995 when protected natural areas were under extraordinary strain. The scientists who assisted drafting the law were quite familiar with legislation from around the world and adopted language that would work within the "new and difficult" economic and political environment [of liberalism]. Section 5 of the preamble is explicit; "Citizens and legal persons, including social and religious associations, shall render assistance to state agencies in realization of the activities of the organization, protection, and use of specially protected natural areas. While fulfilling these activities, state agencies shall take into account proposals of citizens and social associations." ${ }^{41}$ A remarkable statement in light of the fact that Russia does not have a tradition of public participation. In the 1991 Law on Environmental Protection (LEP), citizens are guaranteed the right to demand accurate information, protest, organize meetings, undertake educational programs, appeal decisions on environmental protection and file suit for compensation for damages by polluters. ${ }^{42}$ However, as in US guidelines, no language in either the 1991 LEP nor the 1995 Law on SPNAs mandates agencies to incorporate public proposals into plans, but merely "take into account" proposals of citizens. Nonetheless, protected area advocates see this article as paving the way for expanded public participation.

\section{Cherp 2000.}

38. Mirovitskaya 1998.

39. Bond and Sagers 1992, 463; Menner 1996; and Pryde 1995a.

40. Greenspan 2000, 22-23.

41. Section 5, Federal Law on Specially Protected Natural Areas, Russian Federation, 1995.

42. Foreign Broadcast Information Service 1992, 368-369. 


\section{Liberalism Played Out on Protected Natural Areas}

Zapovedniks ${ }^{43}$ (strict nature preserves) are unique to the Former Soviet Union. Designated as Category 1a under IUCN specifications, ${ }^{44}$ zapovedniks are first and foremost designated for scientific research. The concept to protect an area in its "natural state" for ecological research emerged in the late 1800s in Southern Russia and the Ukraine. After the first federal area was designated in 1917 management decisions have been dominated by the scientific community. ${ }^{45}$ After a 1921 decree by Lenin, the zapovednik system steadily expanded. ${ }^{46}$ The system remained as a notable exception to Soviet policy where environmental conditions were abysmal. Despite a chronic shortage of federal funding and a new generation of management problems, ${ }^{47}$ the post-1991 Russian system has expanded from 77 to 100 zapovedniks protecting over 33 million hectares. ${ }^{48}$

National parks also play an important role in protecting natural resources in Russia. National parks are distinguished from zapovedniks by emphasizing the opportunity for outdoor recreation. The first Russian national park was created in 1983 and there are now 35 national parks. Portions of land managed by other entities may remain within the park "boundary" including towns or agricultural areas. ${ }^{49}$ The goal of the park is to maintain characteristics such as picturesque landscapes, access to waterways, unique natural phenomena or areas for hiking, bird watching, camping etc. One of the greatest challenges for park managers is reconciling park goals with those of the town or agricultural unit on adjacent lands. Typically, parks in Western Russia are a patch work of natural areas and settled areas while the larger parks in Siberia are managed for natural area protection and outdoor recreation. Regulated tourism must not contradict the goals of the national park nor damage its resources.

As a result of inflation and draconian federal budget cuts, most protected areas are operating with 60-80 percent smaller budgets than during the Soviet era. ${ }^{50}$ Research suffers because scientists lack financial and material resources. Enforcement suffers because management is unable to fill law enforcement positions with qualified personnel. Insufficient staffing increases the potential for violations such as poaching for food or income, grazing domestic livestock, and general trespass to collect berries, mushrooms or firewood. A lack of external political support increases the potential for encroachment by homesteaders,

43. These areas were relatively common throughout the USSR (176 in 1990). With some risk of reflecting (perpetuating) the Russian dominance of former Soviet states, we use the Russian word as there is no satisfactory, direct English translation. These areas are designated as "reservats" in the Baltic States.

44. IUCN 1994.

45. Weiner 1999; and Shtil'mark 1996.

46. Weiner 1988; and 1999.

47. Ostergren 1998.

48. Sobolev et al. 1995; and Amirkhanov et al. 1997.

49. Chebakova 1997.

50. Ostergren 1998. 
land development, or cross boundary pollution..$^{51}$ In the extreme, several zapovedniks have fended off attempts by regional officials and industry to dismantle their territory into three parts-a park, an industrial zone and remnant zapovedniks.

Zapovedniks have six goals: a) protection of natural areas; b) conducting scientific research; c) ecological monitoring; d) environmental education; e) participation in Environmental Impact Assessments; f) assistance in training the scientific community. ${ }^{52}$ The first three goals essentially match goals since the $1930 \mathrm{~s}^{53}$ The last three goals are new additions and the inclusion of environmental education (and thus ecotourism) is highly controversial. ${ }^{54}$ Ecotourism may be a path toward fiscal viability; however, some argue that it is inconsistent with the stated purpose of zapovedniks as inviolable regions of natural processes. ${ }^{55}$ Ostergren and Hollenhorst demonstrate a convergence of Russian zapovednik and American Wilderness policy since the 1970s with an acceleration of convergence in the last decade. ${ }^{56}$ Both nations adopted policies and rationales for preserving large natural areas that, while retaining some cultural uniqueness, appear quite similar by 1997. The authors identify several reasons for this convergence including limited alternatives, compliance with international models and agreements, the influence of international NGOs and, in Russia's case, democratization. We go one step further and suggest that the forces of liberalism explain the quickened pace of convergence in the 1990s.

What are the benefits to increased visitation? The first benefit is financiala clear example of the influence of a liberal economy on protected area policy. Managers seek funds from diverse sources such as regional eco-funds, international NGOs, foreign universities to support collaborative research and legal suits against industries who are infringing on the zapovednik property. Traditionalists (academicians, policy analysts, managers) who are concerned about anthropogenic disturbance to flora and fauna, argue that a move toward recreation and tourism is inconsistent with the "true mission" of zapovedniks. ${ }^{57}$ But the allure of foreign income is too strong to ignore. Zapovedniks in high visibility areas with popular megafauna like the Siberian tiger and the snow leopard have real tourism potential. As of 2002 several zapovedniks have already instituted fee systems and programs to benefit from ecotourism. The Altai Zapovednik charges a daily fee per person. Guides who can be engaged may be scientist-instructors (e.g. botanists, ornithologists, geologists) or more recreation oriented. On Katun Zapovednik the fee system is per day and includes an

51. Ostergren 2001.

52. 1995 Law on Specially Protected Natural Areas (RF No. 33-FZ.)

53. Shtil'mark 1996.

54. Ostergren 2001.

55. Rhodes 1998.

56. Ostergren and Hollenhorst 1999.

57. Volkov and de Korte 1994; and Rhodes 1998. 
expert in one field or another. Both zapovedniks have strict regulations on where a group may go, and what individuals may do. For instance, collecting samples is prohibited unless the individual is directly contributing to peerapproved research sponsored by the zapovednik scientific staff. The research may be in conjunction with a Russian or international institution.

National parks have always served the tourist sector but the 1995 legislation places a renewed emphasis on tourism. Managers actively pursue tourism and charge directly for access to the park..$^{58}$ One official pointed out that the United States system for national parks was inherently unfair because many people who never used the National Park System paid for it through taxes. Several other interviewees were willing to at least consider this reasoning as justification for high entrance fees and low federal support for Russian national parks-a clearly entrepreneurial, post-Soviet ideology. Legislative provisions allow for an "economic" zone within the park that may build structures and other tourist infrastructure.

In the end, the relative harm of sacrificing areas to visitors may be minimal compared to the financial and political benefits. The Russian system has the benefit of already established no-visitor zones. This policy has been in effect on the vast majority of zapovedniks and large areas of national parks. Managers thus should still find it relatively easy to protect natural values (e.g. biodiversity, wildness) on the strict protected zones. However, opening to visitors introduces some risk. The Stolby Zapovednik has always permitted recreation on 1500 of its 47,000 hectares. The directors and employees dub the area as their "trouble zone" and have designated an additional 3000 hectares as a buffer zone around tourist areas to absorb trampling, picnics, noise and the general disturbance of human traffic.

The second benefit from increased environmental education/ecotourism is political. Just as Stephan Mather of the US National Park Service promoted visitation in the 1910's to drum up support for US national parks, ${ }^{59}$ the conservation community recognizes that political support can be translated into financial support. Thus, environmental education programs focus on children with an eye to the future. ${ }^{60}$ As more and more people understand the mission and goals of protected areas (so the theory goes), poaching decreases, law enforcement demands decrease, and public support increases. Harsh economic times have limited the success of the strategy but the number of school children participating in environmental education has surpassed Soviet era numbers and educators are optimistic.

As a further example of "entrepreneurship," the cash strapped parks have tapped international NGOs to help organize exchange work programs for trail maintenance. In 2001 not only does Lake Baikal continue to suffer from pulp mill pollution and the effluent pouring down the rivers from cities like Ulan-

58. 1995 Law on Specially Protected Natural Areas (RF No. 33-FZ).

59. Sellars 1997.

60. Ostergren 1995. 
Ude, but illegal banyas (saunas) and vacation home construction add to the pollution. ${ }^{61}$ In response, the international NGO Baikal Ecological Wave has initiated an international effort to monitor and protect Lake Baikal.

A final example of the liberal influence on zapovednik management is illustrated by the implementation of protected area policy. As mentioned, the federal law provides six main goals for zapovedniks under the overall mission to preserve a typical or unique ecosystem as habitat for endemic species and to provide a pristine area for ecological research. In spring 2000, round table discussions with employees from five zapovedniks revealed the effects of individual interpretation. The discussion revolved around how best to fulfill the mission and what to do with the main sticking point of environmental education. From a group that included directors, scientists, educators, inspectors, academics and policy analysts, three variations emerged that represent the main options adopted across Russia: 1) Continue to prohibit access and retain ecological research on the preserve as the primary focus; 2 ) Limit visitation to nearby building areas (or inside museums) and conduct outreach to local communities either with education programs or by conducting research to monitor environmental conditions; 3) Aggressively expand environmental education programs and allow for controlled, more extensive (though not unlimited) access to the preserve. Nikolai Maleshin, the Director of the Zapovednik Directors Association, stated that the particular options are not as important as the fact that each zapovednik has the ability to choose an option within the larger mission. The directors are able to work with the staff to devise a unique strategy to effect their mission. Rather than following specific protocol from Moscow, there is more freedom of interpretation. The implication of options 2 and 3 for the scientific community is that environmental education and "the community needs" have emerged as competing interests. The resident, protected area scientists no longer split the policy-making process with the management staff as a 50/50 proposition since more parties sit at the table.

\section{Russia and the Environmental Impact Statement}

The literature established that liberalism is a tradition drawn specifically from Western Enlightenment thought and this tradition is alive and well in US environmental policy. The environmental impact statement (EIS) is a clear example of the Western liberal paradigm. As another example of liberalization in the Russian Federation, the current expertiza process emerged from Soviet tradition and the influence of new political realities. The federal expertiza is part of a state mandated EIS that must consider all the potential impacts from a project. In addition, properly registered NGOs may respond with their own expertiza, and this expertiza must also be considered in the final decision. ${ }^{62}$

61. Jack 2001.

62. Note that any individual expertiza assessment is part of a larger process that includes industry, state and social organizations' assessments. See Cherp 2000; and Cherp and Lee 1997. 
Wendy Espeland's analysis of the once planned Orme Dam in Arizona depicts the full character of the EIS. Espeland describes how the EIS limits the capacity for "environmental protection and improvement" since protection through the EIS occurs through procedural means that can not admit substantive values beforehand. ${ }^{63}$ Consequently, the liberal EIS easily translated Yavapai Indian Nation resistance, whose ancestral lands were to be inundated by the dam, into reconcilable costs if the tribe could be paid for their troubles. The reaction of a Yavapai teenager to this type of rationality demonstrates the effect of such simplistic comparisons- "The land is our mother. You don't sell your mother." ${ }^{\prime 6}$

The EIS stopped the dam because the costs were too great with the Yavapai land issue as only one of several instrumental reasons. This was a momentary victory for the Yavapai but the real victor was the liberal process of the EIS which took the Yavapai concerns and compared them with parity to other costs and benefits. Thus, the EIS does not make policy through centralized state sponsored values, including science. Instead, it, like US environmentalism en masse, is driven by a plurality of interests that use various disciplines of science for compelling appeal..$^{65}$ The US may be compared to the Soviet system in that prior to the inclusion of impact studies (particularly social impacts), US agencies previously would have based their decisions regarding natural resource use solely on engineering, economic, and environmental grounds and ignored social factors. ${ }^{66}$

With the US EIS in mind, we turn to Russia. Staff in zapovedniks now have the notable added responsibility to help prepare regional expertiza, however underutilized. Initiated in a rudimentary form during the Soviet era in 1985, expertiza function as environmental impact assessments. Zapovednik staff are considered experts on the potential impact of development or extractive activities on neighboring natural territory. The expertiza, much like the US EIS, is largely a cost-benefit tool. However, the Russian variation (first proposed in 1991) carries an obligation by the state to consider an "NGO" expertiza which must then be weighed with the official state and industry sponsored expertiza. The NGO must be willing to fund their study and often struggle to gather important information as some information is deemed "secret." ${ }^{\prime 67}$ Participating in an expertiza, one of the authors witnessed that, typically, NGOs assess a range of concerns including the loss of the spiritual and historic values of areas. In addition, NGOs try to include the raw impacts on villages unfortunate enough to be situated at the bottom of a proposed reservoir or the biodiversity and ecological impacts on an entire ecosystem. Usually the state is allied with industrial inter-

63. Espeland 1994, online.

64. Ibid.

65. Dowie 1996.

66. Boggs 1991.

67. Michail Shishin, Director KATUN NGO and Victor Rudskoi, Professor Barnaul State University. Personal communication with author (Ostergren), Gorni-Altaisk, March 9, 2000. 
ests and indeed industry takes a lead role in conducting the entire assessment process.

Ultimately, the EIS and the expertiza have the power to transform different values into a common metric of utility. While the Soviet regime was expert at deriving this measure, the purpose of the utility and the standard of utility are different in contemporary Russia. Using the EIS cost-benefit process, the utility measure is used for rational decision making amongst competing values. During the Soviet era, the utility value only applied to state values. Within the framework of liberalism, the utility gained through the EIS procedure can be used to decide between values, none of which the state itself is theoretically supposed to endorse prior to the process itself. For Russia (as well as the US), the change from state centered utility to liberal centered utility has not been entirely embraced. However, it's conceivable that in Russia the competing values offer an unstable future for environmental policies such as protected area commitments. In theory, if the utility of a zapovednik becomes too low, the expertiza has the power to abort a proposed zapovednik or transform an existing strict nature preserve into an outdoor recreational park or industrial complex. As mentioned, the Altai Zapovednik has already fought off an attempt to open it up to more tourism or industrial development.

\section{Diminished Power and Increased Participation for Conservation Scientists}

Liberalism has displaced scientists from their central role in decision making for natural resource policy because policy could no longer be seen as coming from authority, but needed to include greater public participation. This involved specific life changes for Russian scientists.

With pluralism defined as the "diffusion and dispersal of power in a political system from central authorities to more or less autonomous groups, organizations and individuals, typically expressed in the establishment of 'bargaining' rather than 'command' relationships between them," Stephan White refers to the scholars of the 1970s and 1980s who anticipated the inevitability of pluralism in the Soviet Union. ${ }^{68}$ The USSR needed pluralism to prosper and the interest groups consolidated as they thought, worked and lobbied together. The scientific interest groups were allied through semi-formal public conservation groups, or rallied as informal groups around issues like preserving Lake Baikal and battling, as Kelly described them in 1976, "institutionalized industrial and commercial lobbies." 69 Post 1991 Russia appears to have more diverse and more vocal interest groups but has not fully developed the network of attitudes, practices and institutions that characterize plural society. ${ }^{70}$ However, within the lib-

68. White $1994,5$.

69. Kelly 1976, 574; and see Pryde 1991, 246.

70. White 1994. 
eral context, the conservation community exemplifies both advantages and disadvantages to the expanding pluralism in $21^{\text {st }}$ century Russia.

Participation is, in part, dependent on access to policy-makers through personal connections and social status. A fundamental deterioration in political status as well as living conditions has limited scientists' ability to make connections and dedicate time and energy to policy issues since the end of the Soviet state. Consistent with the broader literature on the scientific community, ${ }^{71}$ this investigation revealed that conservation scientists fell into three general groups characterized by the degree of change in their work and stature since the fall of the USSR: 1) those at the Russian Academy of Sciences and ministerial level research institutes; 2) academicians at state universities; and 3) the field scientists on nature preserves and national parks.

Scientists who experienced the most dramatic effect to their careers from the fall of the Soviet Union were (or still are) working with Russian Academy of Sciences (RAS) and the research institutes within various ministries (e.g. agriculture, forestry). In the words of one interviewee, "[t]he system collapsed when the government decided that there was little practical return for the investment in theoretical research. Structured as it was, the RAS simply couldn't last. ${ }^{\prime 72}$ The devaluation of the ruble, loss of government revenue, and a general disinterest in theoretical science have eroded nearly all government funding for the RAS and research institutes. Many scientists retain their affiliation with the RAS but rely on a wide range of outside sources for the bulk of their income (typically over $90 \%) .{ }^{73}$ They teach in universities, tutor, work side jobs outside their profession, land occasional grants, consult with Russian and international NGOs, or strive for connections with international universities and organizations. An unforeseen advantage to the RAS diaspora is that NGOs are infused with highly trained scientists familiar with the scientific basis for policy positions. In addition, they can marshal a cadre of experts and lifelong associates to support sympathetic agency positions, or resist environmental threats.

In terms of a change in career, the Russian scientists who seemed least affected by the fall of the Soviet Union were those affiliated with the State University system. The low, but steady salaries are barely enough to live on, however they provide a foundation that can be augmented by other activities. The more successful scientists work together as teams of experts either to perform regional environmental assessments, or pursue grants from international funds. Research funds generally do not support salaries but are applied to infrastructure, buildings, computers, copy machines, phone lines, email and research equipment. Although funds are tight, researchers are pleased with the new freedom

71. Graham 1988; Hammer 1986; and Rezun 1996.

72. Shvarts, Evgeny, Director of conservation of biodiversity project for the Russian office of the World Wide Fund for Nature. Personal communication with authors. Moscow, February, 2000.

73. These findings rely on a limited number (60) of personal interviews and therefore conclusions should be considered with a degree of caution. However, interviewees from disparate sources were very consistent which provides some confidence in generalization and validity. 
(post-Soviet) to choose their own research agenda rather than have it dictated by political authorities. The greatest concern for academicians in this study is that fewer students are opting for advanced degrees and the most promising students are avoiding a career in academia. It appears that the academic community as a whole has less appeal, less prestige and by implication, diminished political clout.

The third group of scientists are those who work in the field on national parks and zapovedniks. After the fall of the USSR, salaries dwindled and money that was budgeted for research disappeared quickly into basic supplies (e.g. gasoline, food) ${ }^{74}$ A few scientists left for other positions, however zapovednik communities offered a steady place to live, a place for the children to go to school, and enough land to squeeze out a living. These factors (in combination with the fact that most employees preferred country to city living) kept the vast majority of scientists on zapovedniks pursuing what research they could with less funding. Clearly, since the fall of the USSR, their ability to collect data on natural resources has been compromised. Just as in the state universities, a tremendous concern for senior scientists is the lack of new, young researchers coming to the zapovedniks. The perception is that life is hard on zapovedniks and young people no longer see the benefits or status that accompanied conservation scientists during the Soviet era.

Among the more revealing aspects of this data is that the most influential scientists, those in RAS, suffered the most dramatic change in prestige, contact, and influence. Perhaps, because they lived far from Moscow the other scientists had less to lose to begin with. Each group, however, has experienced change: from sufficient funding to poverty and dwindling research resources, from a comfortable station in society and policy input to being just another interest group with limited time and money.

Regardless of which group they fall into, scientists have changed their venue for participation. For instance, scientists play an essential role on both sides of the expertiza process making up the bulk of the expert testimony that endorses or discredits proposed projects. However, to have an official voice of dissent, scientists ally with NGOs sponsoring expertiza. The inclusion of civil organization's expertiza was a post-Soviet event apparently to take into account the emerging NGO movement. ${ }^{75}$ Other venues for academicians and researchers is the policy statement, plan or publication usually issued through a "Center" or "think tanks."

The single, most prominent message from all of the respondents was that, technically, the opportunity to influence policy has improved since the Soviet era. However, the means for collecting information to make recommendations has diminished to a level whereby an accurate assessment of conditions is very difficult, if not impossible. While the transition to democracy provides the free-

75. Cherp 2000; and Cherp and Lee 1997. 
dom to voice an opinion, the transition to a market economy has deprived the scientific community the resources to form an opinion. That being said, there is optimism that the economic conditions will eventually stabilize and funding for research will reappear. As one director pointed out, Russia is a resource rich, highly educated country and it will eventually solve its problems.

Although environmentalism peaked during perestroika, there have been a number of remarkable achievements since then. For example, post-Soviet grassroots organizations and the scientific community stopped a hydro-electric dam in the Altai Mountains. ${ }^{76}$ More significantly, scientists and NGOs helped pass the 1995 Law on SPNA and the zapovednik system grew by 50 percent to over 33 million hectares including one that protects the Siberian tiger in the heart of extraordinary forest lands sought by international logging corporations. The World Wide Fund (WWF) for Nature has supported anti-poaching efforts in the Russian Far East. In addition, the national park system has increased by 100 percent to over 6 million hectares, a world heritage site was established in the Altai Mountains, and trans-border agreements have been established with Finland in the northwest and with the United States across the Bering Strait.

In conclusion, some scientists were literally removed from public support because they were considered superfluous. They are now a part of civil society and engaging in private enterprise-something the Russian state is no longer legitimately supposed to publicly sponsor. Other scientists which remained at their posts, such as zapovednik and university scientists were removed politically from a great deal of decision making because the decisions they did make from authority, now needed to be made popularly. In either case, this is a change in institutional role for the Russian conservation scientist.

\section{Conclusion-The View from the Backseat}

In May 2000, President Putin abolished the country's official environmental watchdog, the State Committee on the Environment. In addition, the Federal Forest Service was reorganized to the point of abolishment. The two primary protected area systems, zapovedniks and national parks, were merged under one agency and placed into the Ministry of Natural Resources-a pro-development entity. ${ }^{77}$ Through the rest of 2000 and into 2001 the Deputy Director of the Department of Protection of the Environment and Ecological Security, Vsevelod B. Stepanitski, was attacked by anti-preservation forces within the Duma and the Ministry of Finance. The scientific community, often as NGO representatives, rallied to provide the most recent and up-to-date rationale for maintaining protected areas. As one remarkable result of Director Stepanitski's defense, the budget for protected areas increased in 2001. In addition, the Russian government

76. Misha Shishin, Director of KATUN a Russian NGO in Barnaul, personal interview with author, David Ostergren, August 1995.

77. Anna Badkhen, "Committee's Junking has Greens Fuming," The Moscow Times, May 232000 , 15; and David Hoffman, "Putin Abolishes Russia's Lone Environmental Agency," Washington Post Foreign Service, May 23 2000, A30. 
announced over the next ten years it will establish eight new zapovedniks (506,000 hectares) and twelve new national parks (an additional 10 million hectares that more than doubles the current system), creating a possibility for the current National Park System to become stronger. Clearly, there is a feeling that private groups and individuals, including scientists, can make more bold claims without overly concerning themselves with the Communist Party line as before; however, the conservation policy that occurs now will likely be riddled with the kinds of tensions and tangible inconsistencies that occur in the process itself.

The ironic consequence of our research is that we end up confirming a Marxist-liberal convergence, and in a sense, an East-West convergence. Our assertion has been that a change in Russian political economy, which has been influenced from Western sources such as the United States, marks a change in the structure of natural resource policy. This quite clearly resembles the thesis by Šruba who argues that,

\begin{abstract}
the connecting principle of both doctrines is the conviction that the main functions of society are controlled by an economic mechanism. This conviction, which determines both Marxist and neo-liberal thought, ... that it is political economy which, in Marx's terms, represents the determining part of the anatomy of society .. . ${ }^{78}$
\end{abstract}

Paradoxically, the political economy of Russian natural resource policy confirms the Marxist assertion that social figurations turn on the structure of economic frameworks; but, of course, the economic framework that is adopted is liberal individualism.

If a liberal political economy prefigures any kind of social organization, then it falls prey to its own accusations of authoritarian social domination and hegemony. If a liberal political economy did prefigure Russian nature conservation policy, then liberalism does not offer a full spectrum of choices because policies must answer to the liberal requirements of individualism, instrumental rationality, and markets. Russian policy-makers can no longer limit who is part of the process. Scientists may no longer be assured of insider information and, at times, disproportionate influence on projects. It may be the case that as the stretch of liberalism increases, we will see similar changes in natural resource policy worldwide. If liberalism is spreading as effectively as Fukuyama and others suggest, this may mean that more and more policy-makers around the world will be compelled to fit into a utility (market) model decision making process with a wide variety of interest groups competing to influence outcomes. ${ }^{79}$

According to correspondence with one of the authors of the 1995 SPNA law, the pressing matters after 1991 were that Russian protected areas were going to have trouble, "surviving in that new and difficult economical and political situation. ..." 80 If protected area policy is to survive in a liberal climate, it needs popular political support. This political support is designed both by increasing

78. Šruba 2000, 224 (emphasis added).

79. Fukuyama 1992.

80. Danilina 2001. 
environmental education and making the process of protection pluralistic as in the US. In NEPA, it is through an EIS and potential litigation. In the Russian EIA process, it is an added expertiza, and the added publicity. In both systems, the operative function of the protective law depends on plural interest group response.

The Russian conservation scientists have felt the political force of liberalism. First, by suffering through the declining state economic support and then through a relative decline of influence as industrial, media and inner circle elites ascended in the Kremlin. Although economic conditions can not be ignored, our assertion is that the Russian scientist has seen a change in influence due to the influence of liberalism beyond a collapsed Russian economy.

Scientists' roles have fundamentally changed as a result of the politicaleconomic changes that the rest of the country is experiencing. As scientists left the halls of the Russian Academy of Sciences and joined NGOs, Policy Centers and research institutions, the nature of their participation adopted a pluralistic approach by vying and allying with NGOs and federal agencies. The structure of conservation policy has changed, partially marked by the move of the scientists from state to private organizations-from the front seat to the crowded back where their voices are now part of the din of the rest. Other parts of the conservation/preservation system as a whole have started to adapt as well to the economic liberalism by exploiting various funding opportunities such as ecotourism to the peril of a century old doctrine to 'exclude human activity in order to study natural, undisturbed ecosystems.'

The lessons regarding liberal ideology are not necessarily new, but perhaps they deserve reiterating. One lesson is that liberalism favors individuals and groups that can compete well. In the case of natural resource protection, groups and individuals who care about conserving nature have been relatively successful in promoting their values to some degree in post-Soviet. However, this may not remain the case; as more citizens become accustomed to the new participatory expectations, nature conservation may become more or less valued. The means of competitive civil society is the end in itself for liberalism; nature protection, human rights, economic health, or any other blatant or decreed vision of the good is not. Rather these things can only become temporary visions as the various struggles continue onward indefinitely.

From our perspective, liberalism is a hegemonic political force, which is an ironic position for a political theory averse to authoritarianism. This hegemony comes not from the fact that liberalism is an individualistic political theory, but that it reorganizes power by limiting choices for the good. For better or worse, for Russian scientists, this has meant a move to the backseat.

\section{References}

Amirkhanov, A. M., ed. 1997. First National Report of the Russian Federation "Biodiversity Conservation in Russia." Moscow, State Committee for Environmental Protection.

Barr, Benton, and Kathleen Braden. 1988. The Disappearing Russian Forest: A Dilemma in Soviet Resource Management. Oxford: Rowman and LittleField. 
Bond, A. R., and M. J. Sagers. 1992. Some Observations on the Russian Federation Environmental Protection Law. Post-Soviet Geography 33 (7): 463-474.

Bonnell, Victoria E., and George W. Breslauer, eds. 2001. Russia and the New Century. Boulder: Westview Press.

Boggs, James P. 1991. NEPA in the Domain of Federal Indian Policy: Social Knowledge and the Negotiation of Meaning. Boston College Environmental Affairs Law Review 19 (1) Fall: 31-73.

Breslauer, George.W. 2001. Personalism versus Proceduralism: Boris Yeltsin and the Institutional Fragility of the Russian System. In Russia and the New Century, edited by Victoria E. Bonnell and George W. Breslauer. Boulder: Westview Press.

Chebakova, I. 1997. National Parks in Russia: A Guidebook. Moscow: Biodiversity Conservation Center.

Cherp, Oleg. 2000. Environmental Impact Assessment in the Russian Federation. In Environmental Assessment in Countries in Transition, edited by Ed Bellinger, Norman Lee, Clive George and Anca Paduret. Budapest, Hungary: Central European University Press.

Cherp, Oleg, and Norman Lee. 1997. Evolution of SER and OVOS in the Soviet Union and Russia. EIA Review 17: 177-204.

Cohen, Stephen. 2000. The Failed Crusade: America and the Tragedy of Post-Communist Russia. New York: W.W. Norton.

Danilina, Natalia R. 2001. Personal correspondence via electronic mail. March 16.

Darst Jr., Richard. 1988. Environmentalism in the USSR: The Opposition to the River Diversion Project. Soviet Economy 4 (3): 223-252.

Dowie, Mark. 1996. Losing Ground: American Environmentalism at the Close of the Twentieth Century. Cambridge: MIT Press.

Eckstein, Harry, Fredric J. Fleron Jr., Erik P. Hoffmann, and William M. Reisinger, eds. 1998. Can Democracy take Root in Post-Soviet Russia: Explorations in State-Society Relations. New York: Rowman and Littlefield Publishers.

Espeland, Wendy. 1998. The Struggle for Water: Politics, Rationality, and Identity in the American Southwest. Chicago: University of Chicago Press.

Feshbach, Murray, and Alfred Friendly. 1992. Ecocide in the USSR. New York: Basic Books.

Fish, M. Steven. 2001. When More Is Less: Superexecutive Power and Political Underdevelopment in Russia. In Russia and the New Century, edited by Victoria E. Bonnell and George W. Breslauer. Boulder: Westview Press.

Foreign Broadcast Information Service (FBIS). 1992. April 28. USR-92-049, RSFSR 2060-1 Law on Environmental Protection, 365-386.

Fukuyama, Francis. 1992. The End of History and the Last Man. New York: Free Press.

Gaddy, Clifford G., and Barry W. Ickes. 2001. Stability and Disorder: An Evolutionary Analysis of Russia's Virtual Economy. In Russia and the New Century, edited by Victoria E. Bonnell and George W. Breslauer, 103-125. Boulder: Westview Press.

Goldman, Marshall, I. 1972. The Spoils of Progress: Environmental Pollution in the Soviet Union. Cambridge: Cambridge University Press.

Graham, Loren. 1988. Science Policy and Organization. In The Soviet Union Today: An Interpretive Guide, edited by James Cracraft, 223-233. $2^{\text {nd }}$ edition. Chicago: The University of Chicago Press.

Greenspan Bell, Ruth. 2000. Building Trust: Laying a Foundation for Environmental Regulation in the Former Soviet Block. Environment 42 (2): 20-32.

Gustafson, Thane 1981. Reform in Soviet Politics. Lessons of Recent Politics on Land and Water. Cambridge: Cambridge University Press. 
Hammer, Darrell P. 1986. The USSR: The Politics of Oligarchy. Boulder: Westview Press.

IUCN (The World Conservation Union). 1994. Guidelines for Protected Area Management Categories. Commission on National Parks and Protected Areas with the Assistance of World Conservation Monitoring Centre. Gland Switzerland: IUCN.

Jack, Andrew. 2001. Battle to Protect Russian Lake from Boom in Hot Baths. Financial Times (London). August 3.

Jancar, Babara. 1987. Environmental Management in the Soviet Union and Yugoslavia: Structure and Regulation in Federal Communist States. Durham, NC: Duke University Press.

Jancar-Webster, Barbara. 1993. Eastern Europe and the Former Soviet Union. In Environmental Politics in the International Arena: Movements, Parties, Organizations, and Policy, edited by S. Kamienicki, 199-222. Albany: State University of New York Press.

Josephson Paul R. 1997. New Atlantis Revisited: Akademgorodok, the Siberian City of Science. Princeton: Princeton University Press.

Kelly, Donald, R. 1976. Environmental Policy-making in the USSR: The Role of Industrial and Environmental Interest Groups. Soviet Studies 28 (4): 570-589.

Komorav, Boris (pseudonym for Zeev Wolfson). 1980. The Destruction of Nature in the Soviet Union. White Plains, NY: M.E. Sharpe.

Komarov, Boris (pseudonym for Zeev Wolfson) 1981. Destruction of Nature in the Soviet Union. Society 18 (5): 39-50.

Lubrano, Linda, and Susan Gross Solomon, eds. 1980. The Social Context of Soviet Science. Boulder, Colo.: Westview Press.

Menner, Anya. 1996. ECOJURIS: Pioneers in Russian Environmental Law. Russian Conservation News 6: 17-18.

Micklin, Philip P. 1986. The State of the Soviet Union's North-South Water Transfer before their Abandonment in 1985-86. Soviet Geography 27 (5): 287-329.

Micklin, Phillip, and Andrew Bond. 1988. Reflections on Environmentalism and the River Diversion Projects. In Soviet Economy 4 (3): 253-74.

Mirovitskaya, N. 1998. The Environmental Movement in the Former Soviet Union. In Environment and Society in Eastern Europe, edited by A. Tickle and I. Welsh, 30-66. New York: Addison Wesley Longman.

Ostergren, David. 1995. Two Approaches to the Same Mission. Russian Conservation News 6 February: 5-6.

. 1998. System in Peril: A Case Study of Five Central Siberian Zapovedniki. The International Journal of Wilderness 4 (3): 12-17.

. 2001. An Organic Act after a Century of Protection: The Context, Content and Implications of the 1995 Russian Federation Law on Specially Protected Natural Areas. Natural Resources Journal 41 (1): 125-152.

Ostergren, David M., and Steven J. Hollenhorst. 1999. Convergence in Protected Area Policy: A Comparison of the Russian Zapovednik and American Wilderness Systems. Society and Natural Resources 12 (4): 293-313.

Parrott, Bruce. 1997. Perspectives on Post Communist Democratization. In Democratic changes and authoritarian reactions in Russia, Ukraine, Belerus, and Moldova, edited by Karen Dawisha and Bruce Parrott. Cambridge: Cambridge University Press.

Peterson, Demosthenes J. 1993. Troubled Lands: the Legacy of Soviet Environmental Destruction. Boulder, CO: Westview Press.

1995. Russia's Environment and Natural Resources in Light of Economic Regionalization. In Post-Soviet Geography 36 (5): 291-309. 
Porfiriev, Boris. 1997. Environmental Policy in Russia: Economic, Legal and Organizational Issues. In Environmental Management 21 (2): 147-157.

Pryde, Philip R. 1972. Conservation in the Soviet Union. New York: Cambridge University Press.

. 1991. Environmental Management in the Soviet Union. New York: Cambridge University Press.

ed. 1995. Environmental Resources and Constraints in the Former Soviet Republics. Boulder, CO: Westview Press.

1995a. Russia: An Overview of the Federation. In Environmental Resources and

Constraints in the Former Soviet Republics, edited by Philip R. Pryde. Boulder, CO:

Westview Press.

Rezon, Miron. 1996. Science, Technology, and Ecopolitics in the USSR. Westport: Praeger Publishers.

Rhodes, Olin E. 1998. Ecotourism: Direct Road to Ruin. In Russian Conservation News 17: 20.

Ridgeway, Sharon. 1996. Critique of the Mechanistic Paradigm for Environmental Policy. Dissertation. Northern Arizona University.

Saivetz, Carol R., and Anthony Jones, eds. 1994. In Search of Pluralism: Soviet and PostSoviet politics. Boulder: Westview Press.

Sale, Kirkpatrick. 1993. The Green Revolution: The American Environmental Movement 1962-1992. New York: Hill and Wang.

Sakwa, R. 1996. Russian Politics and Society. $2^{\text {nd }}$ edition. London: Routledge Publishing.

Sellers, R. W. 1997. Preserving Nature in the National Parks: a history. New Haven: Yale University Press.

Shaposhnikov, L. K., and V. A. Borisov. 1958. Pervi meropriyatiya Sovietovo Gosudarstva po okhrana prirodi [First measures of the Soviet government of nature protection]. Okhrana Prirody i Zapovednoe Delo V SSSR 3: 93-98.

Shtil'mark, Felix R. 1996. Istoriografiya Rossiskikh Zapovednikov (1895-1995). [The Historiography of the Russian Nature Preserves]. Moscow, TOO, Logata.

Skilling, H. Gordon, and Franklyn Griffiths, eds. 1971. Interest Groups in Soviet Politics. Princeton: Princeton University Press.

Smith, Zachary A. 2000. Environmental Policy Paradox.,3rd edition. Englewood Cliffs, NJ: Prentice Hall Publishers.

Sobolev, Nikolai A., Evgeny A. Shvarts, Mikhail L. Kreindlin, Vadim O. Mokievsky, and Victor A. Zubakin. 1995. Russia's Protected Areas: A Survey and Identification of Development Problems. In Biodiversity and Conservation 4: 964-983.

Šruba, Ilja. 2000. Neo-Liberalism, Post-Communist Transformation, and Civil Society. In The Meaning of Liberalism-East and West, edited by Zdenek Suda and Jirí Musil, 125. New York: Central European University Press.

Suda, Zden k. 2000. By Way of Introduction. In The Meaning of Liberalism-East and West, edited by Zdenek Suda and Jirí Musil. New York: Central European University Press.

Volkov, Andrei E., and Jon de Korte. 1994. Protected Areas in the Russian Arctic. In Polar Record 30 (175): 299-310.

Weigle, Marcia. 2000. Russia's Liberal Project: State-Society Relations in the Transition from Communism. University Park: The Pennsylvania State University Press.

Weiner, Douglas R. 1988. Models of Nature: Ecology, Conservation, and Cultural Revolution in Soviet Russia. Bloomington, IN: Indiana University Press. 1999. A Little Corner of Freedom. Berkeley: University of California Press. 
White, Stephan. 1994. Pluralism, Civil Society, and Post-Soviet Politics. In In Search of Pluralism: Soviet and post-Soviet Politics, edited by Carol R. Saivetz and Anthony Jones. Boulder: Westview Press.

. 2000. Russia's New Politics: The Management of a Postcommunist Society. Cambridge: Cambridge University Press.

Yablokov, Alexei V., and S. A. Ostroumov. 1991. Conservation of Living Nature and Resources: Problems, Trends, and Prospects. New York: Springer-Verlag.

Yanitsky, Oleg. 1993. Russian Environmentalism: Leading Figures, Facts, Opinions. Moscow: Mezhdunarodnyje Otnoshenija Publishing House.

Ziegler, Charles E. 1987. Environmental Policy in the USSR. Amherst: University of Massachusetts Press. 
Copyright $\odot 2003$ EBSCO Publishing 